\title{
Late Carboniferous biota from the Ljubija iron mine area, Bosnia and Herzegovina
}

\section{Poznokarbonska biota z območja rudnika železa Ljubija v Bosni in Hercegovini}

Aleksej MILOŠEVIĆ ${ }^{1}$, Alexander S. ALEKSEEV 2,3 , Elena ZAYTSEVA², Matevž NOVAK ${ }^{4}$, Tea KOLAR-JURKOVŠEK ${ }^{4} \&$ Bogdan JURKOVŠEK ${ }^{5}$

${ }^{1}$ University of Banja Luka, Faculty of Mining, e-mail: aleksej.milosevic@rf.unibl.org;

${ }^{2}$ Faculty of Geology, Lomonosov Moscow State University, Leninskie Gory 1, 119991 Moscow, Russia; e-mail: aaleks@geol.msu.ru; ezaitseva@mail.ru;

${ }^{3}$ Borissiak Paleontological Institute, Russian Academy of Sciences, Profsoyuznaya 123, 117647 Moscow, Russia;

${ }^{4}$ Geological Survey of Slovenia, Dimičeva ulica 14, SI-1000 Ljubljana, Slovenia; e-mail: matevz.novak@geo-zs.si; tea.kolar-jurkovsek@geo-zs.si

${ }^{5}$ Kamnica 27, 1262 Dol pri Ljubljani, Slovenia; e-mail: geolog.bj@gmail.com

Prejeto / Received 14. 4. 2021; Sprejeto / Accepted 1. 7. 2021; Objavljeno na spletu / Published online 19. 7. 2021

Key words: Upper Carboniferous, Pennsylvanian, Algae, Foraminifera, Conodonts, Olistoliths, Sana-Una Paleozoic

Ključne besede: zgornji karbon, pennsylvanij, alge, foraminifere, konodonti, olistoliti, Sansko-unski paleozoik

The Olistostrome member of the Sana-Una Paleozoic complex of the Ljubija ore mine in Bosnia and Herzegovina contains limestone fragments of pebble to block size that have been examined paleontologically. The recovered conodont fauna of the first sample is characterized by the species Declinognathodus lateralis, Idiognathoides sulcatus sulcatus and Idiognathodus sp. confirming its mid-Bashkirian age. This report is the first on the occurrence of these taxa in the area. The second sample with chaetetid demosponges yields an abundant diversified microbiota consisting of cyanobacteria, algae and foraminifera. Chlorophyts are marked by the common siphonoclad occurrence of Donezella lutugini and D. lunaensis, whereas rhodophyts include rare representatives of Stacheia, Stacheoides, Pseudoungdarella and Masloviporidium. The presence of Asphaltinella horowitzi and Aphralysia carbonaria of unclear taxonomic position is also documented. Pseudostaffellids, eostaffellids and other foraminifera, mostly endothyrids are present. The examined associations of fossils point to the Bashkirian age of the primary rock that originated in a very shallow habitat most probably linked to a high-energy reef environment.

\section{Izvleček}

Olistostromski člen v Sansko-unskem paleozojskem kompleksu rudnika Ljubija v Bosni in Hercegovini vsebuje apnenčaste prodnike in bloke, ki so bili paleontološko raziskani. Konodontno favno prvega vzorca označujejo Declinognathodus lateralis, Idiognathoides sulcatus sulcatus in Idiognathodus sp., ki dokazujejo njegovo srednjebaškirijsko starost. To je prvo poročilo o pojavu teh taksonov na tem območju. Drugi vzorec s hetetidno demospongijo vsebuje bogato in raznoliko mikrobioto, ki jo sestavljajo cianobakterije, alge in foraminifere. Med klorofiti so pogoste sifonoklade Donezella lutugini in D. lunaensis, med rodofiti pa so redki predstavniki Stacheia, Stacheoides, Pseudoungdarella in Masloviporidium. Dokumentirana je tudi prisotnost Asphaltinella horowitzi in Aphralysia carbonaria z nejasnim taksonomskim položajem. Foraminifere zastopajo psevdostafelide, eostafelide in manjše foraminifere, večinoma endotiride. Raziskana združba kaže na baškirijsko starost izvorne kamnine, ki je nastala v zelo plitkem habitatu, verjetno povezanim z visokoenergijskim grebenskim okoljem.

\section{Introduction}

The Ljubija siderite ore field is located around $200 \mathrm{~km}$ northwest of Sarajevo (Fig. 1), in Bosnia and Herzegovina, and belongs to the Sana-Una Paleozoic complex (Hrvatović, 2006). Together with the Mid-Bosnian Schist Mountains, the Paleozoic strata of eastern and southeastern Bos- nia represents the Paleozoic complexes of the Dinarides in Bosnia and Herzegovina that are not genetically related to the Mesozoic-Paleogene evolution of the Tethys (Hrvatović, 2006). The boundaries of the Sana-Una Paleozoic complex are defined based on an unclear contact with younger strata (northeastern and southwest- 
ern boundary), and in parts where tectonic elements are not expressed, the boundaries are set based on topographic criteria (Jurić, 1971). In the northwest, the Sana Paleozoic complex is separated from the Banija by the Una River, and in other parts it is limited by the Mesozoic strata; to the south is the front of the Sana Nappe, to the east the border of the Jurassic and Cretaceous formations, and to the north the inner ophiolite zone of Kozara. The area features interesting geological phenomenon due to the well known and potentially exploited deposits of iron and other raw minerals.

The first studies of the Sana Paleozoic complex commenced with the investigation of Austrian geologists (e. g. Mojsisovics et al., 1880) and later the iron ores near Ljubija were part of detailed examinations of Katzer (1910, 1921, 1926). The new evidences were obtained interpreting the Carboniferous sediments as turbidite deposits that contained mineralized limestone olistoliths. The entire Carboniferous sequence has been severely hydrothermaly influenced (Stefanovska, 1990). Later, these Carboniferous sediments were genetically considered as typical flysch deposits where a significant amount of limestone olistoliths occur (Grubić et al., 2000).

Katzer (1926) was the first who considered the Paleozoic formations of the wider area of Ljubija to be Late Carboniferous in age and his view has been accepted by later researchers (Simić, 1940; Heritsch, 1940; Crnolatac, 1949; Noeth, 1952). However, paleontologic evidence for the Early Carboniferous age of the limestone in the Sana-Una Paleozoic complex was provided by Kostić-Podgorska (1955) based on the coral fauna. Data on fossils found in the Sana-Una Paleozoic complex were successfully systematized by Jurić (1971). The faunas obtained in the olistoliths evidenced the Devonian, Early and Late Carboniferous and according to Grubic et al. (2000) the age of the Olistostrome member is assigned to the topmost Early to Late Carboniferous.

An important study on siderite-barite-polysulfide deposits of the Middle Dinarides, considering the Ljubija ore region, was published by Palinkaš (1990). In the last decades the research concept has been severely based on the metallogeny of this ore region. More recent geochemical examinations of the Ljubija mines resulted in interpretation that ore origin is hydrothermal-metasomatic and that the mineralization is of Permian age (Strmić-Palinkaš et al., 2009; Garašić \& Jurković, 2012; Palinkaš et al., 2016). More recent data on the geology and metalloge- ny of the Ljubija ore region are presented in the works of Grubić et al. (2015) and Milošević et al. (2017).

Conodonts have demonstrated their value for biostratigraphy and they are one of the leading microfossil groups in the interpretation of the biostratigraphy of Paleozoic and Triassic marine strata. As they have proven their practical value as parastratigraphic fossils, the main goal of our study is to examine conodont faunas from the Ljubija area. The conodonts of the Sana-Una Paleozoic strata are scarce. During the mapping of the Geological map of SFRY 1: 100,000 they were identified and described at two locations sites (Jurić, 1975). The tentaculite finds at Blagaj already determined in the field the pre-Carboniferous age of the limestones, and based on lithological analogy with the Devonian limestones of Družetić in western Serbia, a Devonian age was assumed, which was confirmed by the conodont examination (Spasov \& Filipović, 1966). The conodont fauna from the Blagaj limestone is characterized by the presence of representatives of the genus Palmatolepis, which first appears in the Late Devonian. The list of the identified taxa includes: Palmatolepis glabra glabra, P. minuta, P. subperlobata, Polygnathus glabra glabra, Po. nodosocostata nodosocostata that are ranged in the interval of the Famennian crepidarhomboidea zones (Spasov \& Filipović, 1966).

Another locality is a site south of Prijedor. A conodont fauna of a smaller limestone block, was discovered in a road-cut Ljubija - Sanski Most, about $2 \mathrm{~km}$ south of th Adamuša opencast mine. Dark grey limestone contains a rich brachiopod and cephalopod fauna (Stojanović-Kuzenko, 1967); the conodont fauna recovered from this block yields Gnathodus bilineatus and Lochriea commutata commutata (Spasov \& Filipović, 1966). This site was recollected by Ramovš (1990) who added to these listed conodont taxa also $L$. mononodosa and $L$. nodosa that enabled this fauna to be re-assigned to the nodosa Zone (Visean, Early Carboniferous).

The purpose of this study is to examine conodont fauna of newly collected samples from the Ljubija mine area, as well as to provide additional data from another sample with a demosponge specimen obtained in a carbonate olistolith from the Adamuša site. The latter sample yields rich algal and foraminiferal associations that are also documented herein. The biostratigraphic and paleogeographic significance of the determined taxa is also provided. 


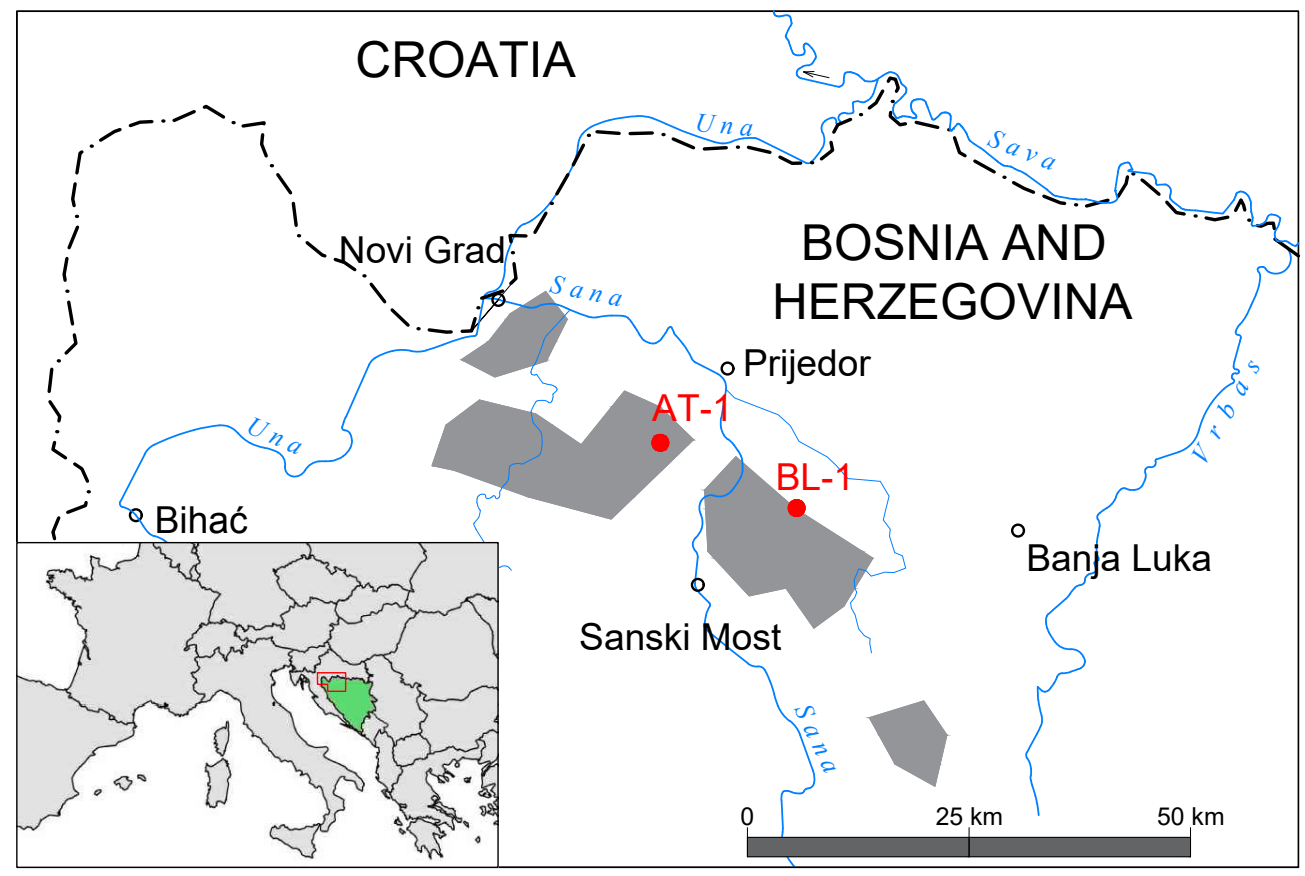

Fig. 1. Index maps with the location of the Ljubija ore mine. (a) Map of NW Bosnia and Herzegovina with marked areas of the Sana-Una Paleozoic complex (gray). Red dots indicate the position of the examined samples. (b) Geographic position of the area shown in Figure 1a; area of Bosnia and Herzegovina marked in green.

\section{Materials and methods}

For micropaleontologic study the conodont sample AT-1 (Fig. 1) was collected (by BJ and TKJ) in the Adamuša opencast mine in 2019 during the field trip of the Congress of geologists in Bosnia and Herzegovina. The collecting of this bed was repeated as this sample proved to be productive for conodonts, and thus an additional quantity of the rock was provided in 2020 (by AM). The coordinates of the sample AT-1 are: $44^{\circ}$ 54' 34" E; $16^{\circ} 36^{\prime} 18$ " N. For this study we added information about the sample with a demospongia specimen that was collected in 1974 near the location of the conodont sample AT-1, a locality that is today already flooded; the specimen is housed in the Paleontological collection of Jurkovšek, Dol pri Ljubljani under the inventory number BJ 49. Another sample (BL-1) for conodonts was collected in the locality Blatnjak (coordinates $44^{\circ} 50^{\prime} 43^{\prime \prime} \mathrm{E} ; 16^{\circ} 48^{\prime} 04^{\prime \prime} \mathrm{N}$ ) that turned out to be devoid of microfauna.

The sample AT-1 with a total rock weight of $6 \mathrm{~kg}$ was processed for conodonts. A standard technique for processing conodont samples with the use of diluted acetic acid (5-8 \%) was applied and followed by heavy liquid separation. The laboratory preparation was carried out at the Geological Survey of Slovenia, Ljubljana where the residue is also stored in the micropaleontological collection and inventoried under the repository number GeoZS 6219 and 6220. The illustrated conodont elements presented in this paper were photographed by the JEOL JSM 6490LV Scanning Electron Microscope at the Geological Survey of Slovenia.
A total of 11 petrographic thin sections have been made from the host rock from the sample with demospongia (sample BJ). Three thin sections were stained by Alizaren Red S and K-ferricyanide. All thin sections were photographed with magnifications $\times 12.5, \times 25$ and $\times 50$. All 11 thin sections were used also for the study of the foraminifera and algae. Foraminifera occur in all of the studied thin sections.

\section{Geological setting}

The Sana-Una Paleozoic complex is located east of the Una River. It extends over the area from Novi Grad through Prijedor to Sanski Most, Budimlić Japra, Ključ and Mrkonjić Grad where the most widespread strata belong to the Javorik flysch formation (Fig. 2).

The Ljubija deposits are set in its Carboniferous part belonging to the Javorik flysch formation where the majority of the mineral resources are emplaced within the Olistostrome member. The Javorik flysch formation is well exposed in the Adamuša and Tomašica opencast mines that is, accoring to Grubić et al. (2015), composed of three members, i.e., the Pre-flysch and Lower flysch, Olistostrome member and Upper flysch (Fig. 2).

The basal unit of the Javorik flysch formation is the Pre-flysch and Lower flysch member consisting of dark argillaceous schists with alternation of medium-grain sandstone. It is well studied in the Adamuša opencast mine, in a core of large anticline structure. This member was probably formed in a deeper marine environment (Grubić et al., 2015). 

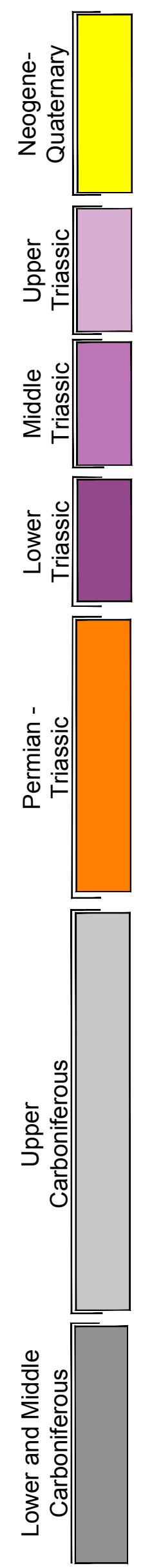

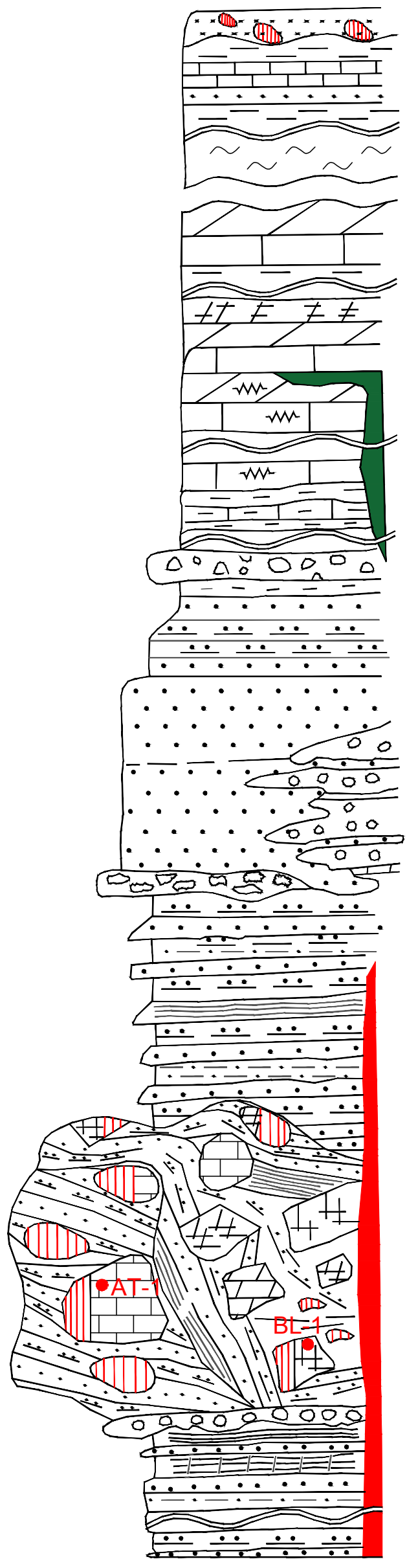

Marls, shales, limestones and sandstones and locally re-deposited Fe ore

Dolostones with limestones and marl intercalations

Limestones, dolostones with chert and silicious marls

$\stackrel{\infty}{\frac{4}{2}}$

Limestones, marly limestones, marlstones and breccias के (Werfen formation)

Red siltstones and
sandsones

Red and white sandstones

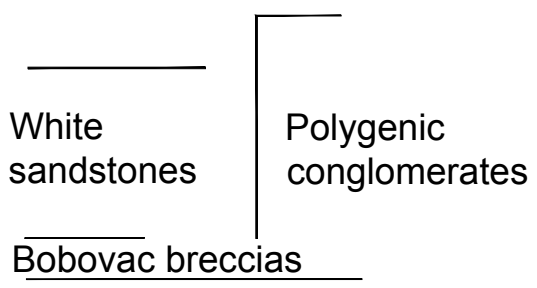

Upper flysch: siltstones, metasiltstones, sandstones and shales

\section{Olistostrome member:} flysch matrix (siltstones, sandstones, shales), olistolithic blocks (limestone, dolostone), mineralized bodies (siderite, ankerite) and autoclastic melange

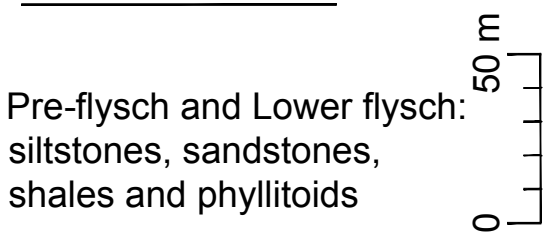


The Pre-fysch and Lower flysch member is overlain with the deposits of Olistostrome member. The thickness of this member varies between 100 to $300 \mathrm{~m}$. It consists of flysch matrix with embedded carbonate olistoliths - boulders and blocks and their mineralized parts. The mineralized bodies are represented by siderite and ankerite. Carbonate fragments and blocks or boulders of the Olistostrome member include black micrite, dark grey organogenic sparite (rich in fossils), dolomitic limestone and dolostone, ankeritic limestone and ankerite. Within the Olistostrome member some authors distinguished more units, i.e. a Siderite-limonite member, and Wild flysch and Middle flysch (Grubić \& Protić, 2003; Garašić \& Jurković, 2012). The Olistostrome member was formed under deep-water conditions (Grubić \& Protić, 2003) found in the core of the Sana antiform. The studied samples originate from this unit.

The youngest member of the Javorik flysch formation is the Upper Flysch member that is also the most widespread member of the Sana-Una Paleozoic complex. It is well exposed in the Tomašica opencast where it attains thickness of $70 \mathrm{~m}$. It is mainly formed of sandstone-siltstone flysch. Due to Mn oxides and hydroxides particularly, its lower part is black in colour (Grubić \& Protić, 2003).

The Permian-Triassic clastic formation appears in discontinuously exposed zones in the north and south limb of the Sana antiform and south from the Sana Nappe. Its maximum thickness is estimated to $150 \mathrm{~m}$. According to Grubić and Protić (2003), five members can be distinguished: a) Bobovica breccia, b) white sandstone, c) white and red sandstone, d) polygenous conglomerate and e) red sandstone and siltstone. Also present are porous dolomite (of a rauhwacke-type), and siderite veins, up to $40 \mathrm{~cm}$ long in some places.

The colourful Werfen strata are overlain by limestone and dolomite, covered by a Ladinian volcanogenic-sedimentary porphyrite-chert formation. Among the younger sedimentary rocks, only lacustrine Neogene - Quaternary deposits are present.

The tectonic history of this area is very complex as it was a consequence of Hercynian, Cimmerian and Alpine deformation phases. Hercynian events left their signatures only in the Javorik flysch formation, in the form of folds whose B-axes have an azimuth of 10 to $40^{\circ}$. The dispersion of the $\mathrm{B}$-axis is a consequence of Alpine refolding (Grubić \& Protić, 2003).

\section{Results}

\section{Microfacies}

The microfabric of the rock sample BL-1 with chaetetid demosponge is irregular, peloidal bioclastic grainstone to packstone. In one of the thin-sections also biosparite micro-breccia (rudstone) is present.

Bioclasts and peloids (algal and microbial) predominate. Intraclasts and pellets also occur. Bioclasts are represented by algae, cyanobacteria and foraminifera are most common. Many echinoderm (mostly crinoid) fragments also occur together with rare thin bivalve shells, small gastropods and ostracods. Very rare are fragments of brachiopods. Intraclasts contain bioclasts and pelmicrite. Echinoderm fragments are up to $1 \mathrm{~cm}$, most of them, and also other bioclasts, exhibit abraded margins with replacements by micrite.

The rock is crosscut with several thin white calcite veins and a few thicker ones. It exhibits weak to strong irregular stylolitization.

\section{Foraminifera}

Foraminifera in the BJ 49 sample belong to groups of pseudostaffellids, eostaffellids and smaller foraminifera, mostly endothyrids. Determination on a species level is hindered because of the lack of oriented sections. In the studied material, several specimens of the genus Pseudostaffella are found, which in general can be assigned to the Pseudostaffella ex gr. antiqua (Dutkevitch) species group (Rauser-Chernousova et al., 1951). By the position of the coiling axes and the character of the chomata, the specimens are identified as Pseudostaffella antiqua (Dutkevitch), Ps. grandis Schlykova, Ps. cf. posterior Safonova, and ?Ps. cf. proozawai Kireeva (Pl. 1, Figs. a-e). In general, these forms are slightly smaller in size compared to those common in the Russian Platform and in the Urals (Grozdilova \& Lebedeva, 1950; Rauser-Chernousova et al., 1951).

Among forms assigned to the genus Eostaffella, the following species are identified: Eostaffella pseudostruvei chomatifera Kireeva, $E$. parastruvei chusovensis Kireeva, and E. cf. parastruvei chusovensis Kireeva (Pl. 1, Figs. $\mathrm{f}-\mathrm{i})$. The genus Plectostaffella is represented by Plectostaffella varvariensis (Brazhnikova \& Potievskaya), P. ex gr. bogdanovkensis Reitlinger; P. cf.irregularia (Reitlinger); P.ovoideaformis (Reitlinger) (Pl. 1, Figs. j-n). Also present is the genus Semistaffella with the species $S$. variabilis (Reitlinger), S. primitiva (Reitlinger), 


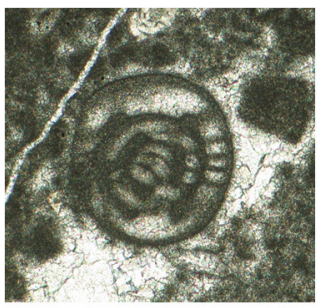

a

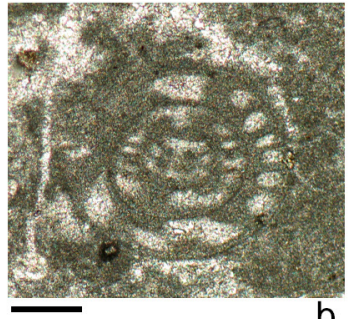

b

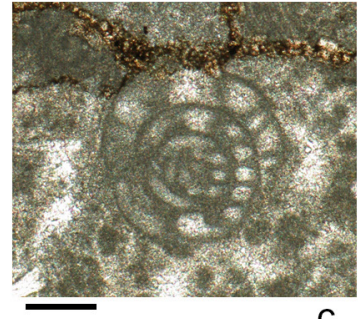

C
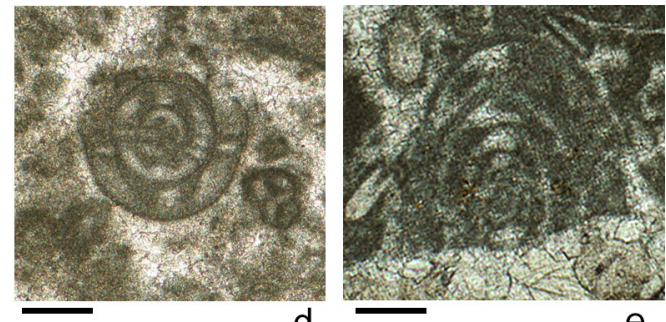

d
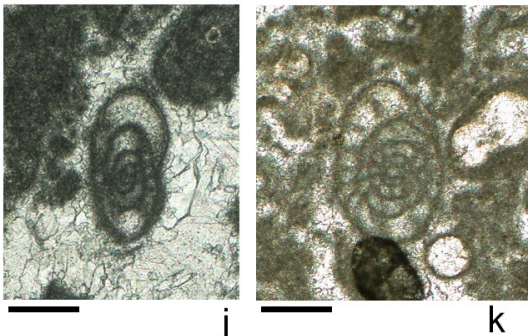

$\mathrm{h}$
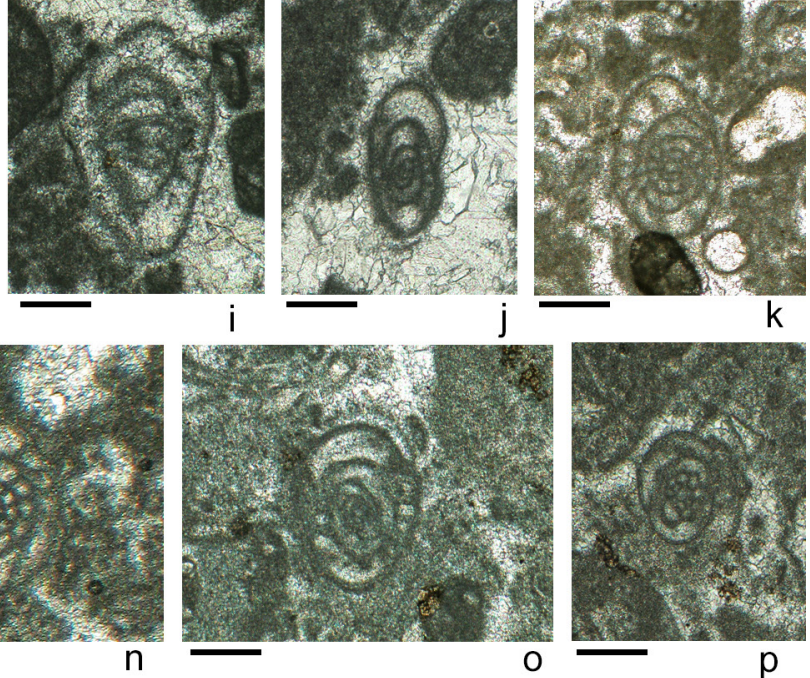

$\mathrm{p}$

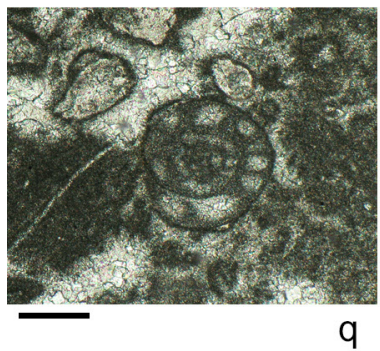

q
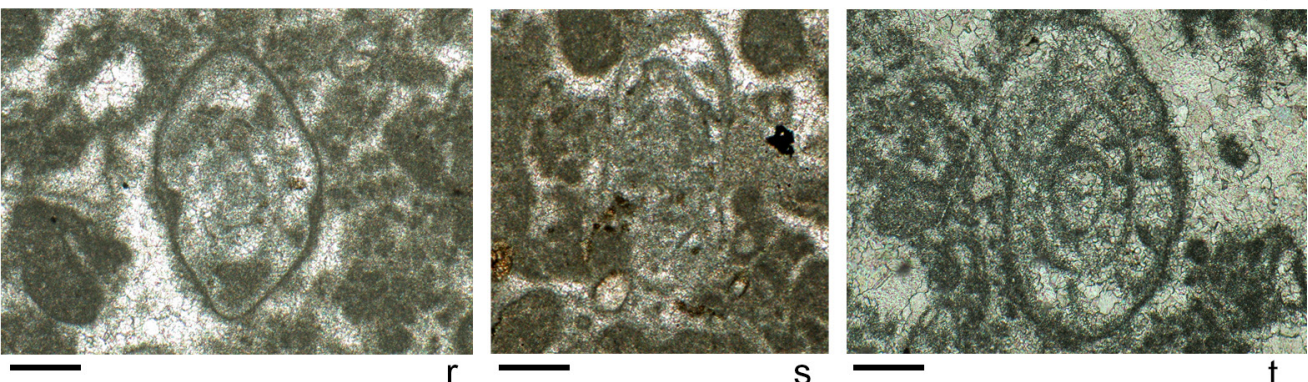

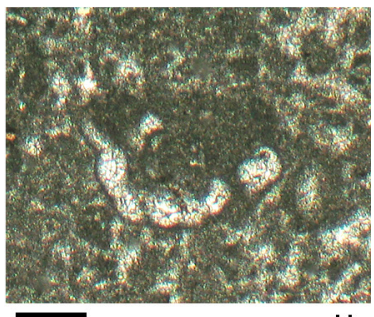

u
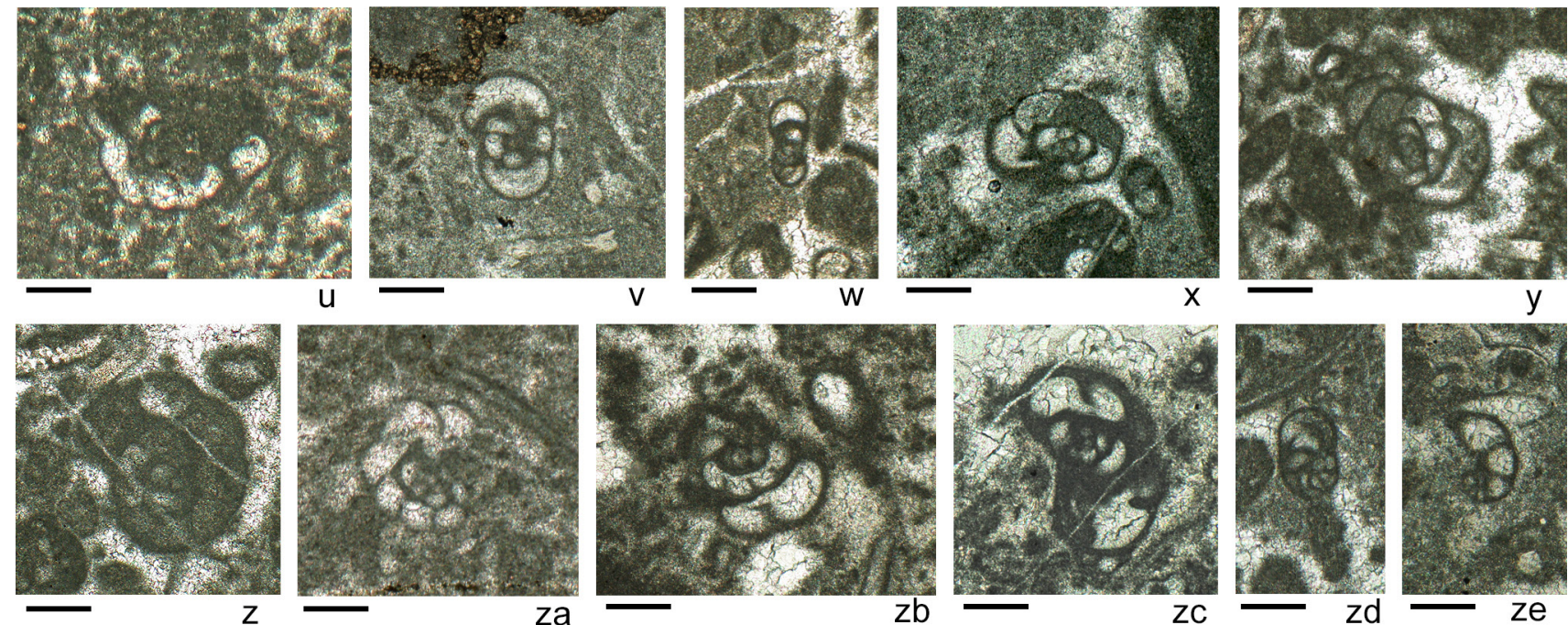

Plate 1. Fusulinoidean and smaller foraminifera from Ljubija, sample BJ 49. Scale bar is 200 microns.

(a): Pseudostaffella antiqua (Dutkevitch), (b, c): Pseudostaffella grandis Schlykova, (d): Pseudostaffella cf. posterior Safonova, (e): ?Pseudostaffella cf. proozawai Kireeva, (f): Eostaffella pseudostruvei chomatifera Kireeva, (g): Eostaffella parastruvei chusovensis Kireeva, (h): Eostaffella cf. parastruvei chusovensis Kireeva, (i): Eostaffella sp., (j): Plectostaffella varvariensis (Brazhnikova \& Potievskaya), (k): Plectostaffella ex gr. bogdanovkensis Reitlinger (1): Plectostaffella ovoideaformis (Reitlinger), (m): Plectostaffella cf. irregularia (Reitlinger), (n): Plectostaffella sp., (o): Semistaffella variabilis (Reitlinger), (p): Semistaffella primitiva (Reitlinger), (q): Semistaffella minor (Rauser-Chernousova), (r): Parastaffella cf. struvei (Möller), (s): Parastaffella cf. poststruvei Rauser-Chernousova, (t): Parastaffella sp., (u): ?Endothyra sp., (v): Endothyra bradyi simplex Reitlinger, (w, x): Endothyra sp. (E. ex gr. bradyi Mikhailov), (y): Endothyra mutabilis Reitlinger, (z): Endothyra cf. mosquensis Reitlinger, (za): Endothyra bradyi compressa Reitlinger, (zb): Endothyra sp. (E. cf. mosquensis Reitlinger), (zc): Planoendothyra ex gr. spirilliniformis (Brazhnikova \& Potievskaya), (zd): Biseriella minima (Reitlinger), (ze): Biseriella ex gr. moderata (Reitlinger). 
and S. minor (Rauser-Chernousova) (Pl. 1, Figs. o-q). A few lenticular forms with acute margins belong to Parastaffella cf. struvei (Möller) and P. cf. poststruvei Rauser-Chernousova (Pl. 1, Figs. $r-$ t).

Endothyrids are represented in significant amounts. The species Endothyra ex gr. bradyi Mikhailov, E. bradyi compressa Reitlinger, E. mutabilis Reitlinger, E. cf. mosquensis Reitlinger, and Planoendothyra ex gr. spirilliniformis (Brazhnikova \& Potievskaya) were recognized (Pl. 1, Figs. u-zc).

Accompanied foraminifera, occuring in small amounts are Globivalvulinidae (Biseriella minima (Reitlinger) and $B$. ex gr. moderata (Reitlinger) (Pl. 1, Figs. zd, ze), Bradyinidae (Bradyina ex gr. nautiliformis Möller and ?B. pseudonautiliformis Reitlinger) (Pl. 2, Figs. a-c), Palaeotextularioidea (Koskinobigenerina aljutovica (Reitlinger); Koskinotextularia posteximium (Reitlinger), Deckerellina cf. mirabilis Reitlinger (Pl. 2, Figs. d-g) and Neoarchaediscus postrugosus (Reitlinger) (Pl. 2, Fig. h), Tuberitina bulbacea Galloway \& Harlton (Pl. 2, Fig. i), ?Tolypammina ex gr. complicata Reitlinger (Pl. 2, Fig. j), Postmonotaxinoides cf. horridus (Lipina) (Pl. 2, Fig. k), and Pseudoglomospira cf. elegans (Lipina) (Pl. 2, Fig. 1).

In the International Stratigraphic Scale (Aretz et al., 2020), the base of the Bashkirian Stage (base of the Pennsylvanian) is marked by the appearance of the conodont Declinognathodus noduliferus. This level correlates with the base of the ammonoid Homoceras Zone and the base of foraminiferal Plectostaffella bogdanovkensis Zone. The P. bogdanovkensis Zone is traced in the Urals (Kulagina, 2014), in the Caspian Region (Zaytseva \& Klenina, 2008), and in Middle TienShan (Dzhenchuraeva et al., 2013).

The appearance of the species Pseudostaffella antiqua (Dutkevitch) is a noticeable level in the evolution of fusulinids corresponding to the middle part of the lower Bashkirian (the base of the Akavasian Regional Substage in Urals or Severokeltmenian Regional Substage of the Russian Platform) and is distinguished as the rapid diversification of pseudostaffellids (Kulagina \& Gorozhanina, 2019). The represented species of the genera Eostaffella, Plectostaffella and Semistaffella are characteristic of the lower Bashkirian. The species Plectostaffella varvariensis (Brazhnikova \& Potievskaya) is known from the top of the Serpukhovian. P. bogdanovkensis is a zonal marker of the Serpukhovian/Bashkirian boundary of the East European Platform and the
Urals. The genus Semistaffella appears slightly higher. There are transitional forms between them as well as between Semistaffella and primitive Pseudostaffella.

During the Early Carboniferous, the genera and species of the Ozawainellidae and Staffellidae were common in shallow carbonate shelves and in basins of nearly all regions of the world (BouDagher-Fadel, 2008). The diversity of the fusulinids and their related forms increased at the Serpukhovian-Bashkirian boundary. Foraminiferal provinces have been clearly distinguished already since late Famennian (Lipina, 1973) with three different provinces becoming recognizable: the East European Basin that are characterized by an abundance of Eostaffella and Bradyina; the Tethyan Realm, where the palaeotextulariids were abundant; and the North American Realm, where Bradyina did not appear before the Bashkirian.

During the Late Carboniferous (Bashkirian to Gzhelian), the endothyrids, staffellids and bradyinids may have colonized their habitats within or in adjoining high-energy environments (Dingle et al., 1993; Della Porta et al., 2005). The endothyrids were common in low- and high-energy settings. Their exclusion from lagoonal environments with a restricted circulation and variable salinity suggests that these forms preferred open-marine environments (Della Porta et al., 2005). The lenticular staffellids are abundant in higher energy, reef facies, whereas the subspherical forms were common in the quieter, back reef facies (Dingle et al., 1993), in the shallowest setting and in paleoenvironments characterized by abnormally high temperatures and salinity. The Bradyinidae were probably epiphytes and Bradyina is interpreted as a shallow-water taxon adapted to life in current-swept environments (Gallagher, 1998; Gallagher \& Somerville, 2003; BouDagher-Fadel, 2008).

\section{Cyanobacteria and algae}

The remains of cyanobacteria are very common in the studied thin sections (Pl. 2, Figs. m-o). They are similar to the remains of filament-forming and coccoid bacteria described by Mamet \& Preat (2010) from Bashkirian foraminifer zones 20 and 21 of Arctic Alaska. Besides the remains of Girvanella sp. (Pl. 3, Fig. d) also Stipulella fascicularis Maslov (Pl. 2, Figs. r-s) is identified. This species was described from the Lower Carboniferous of the Moscow Basin (Maslov, 1956). It is distributed in the Kizelian Regional Substage of the upper Tournaisian and the upper part of 

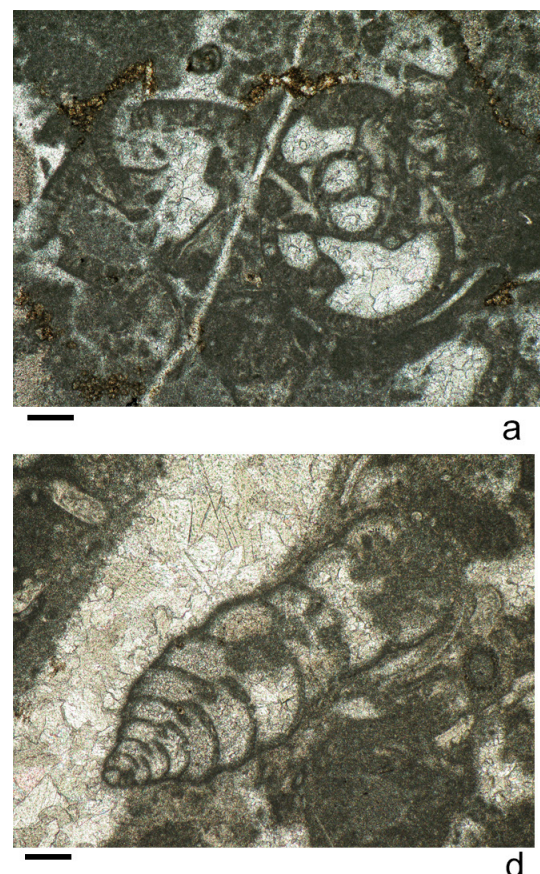

d
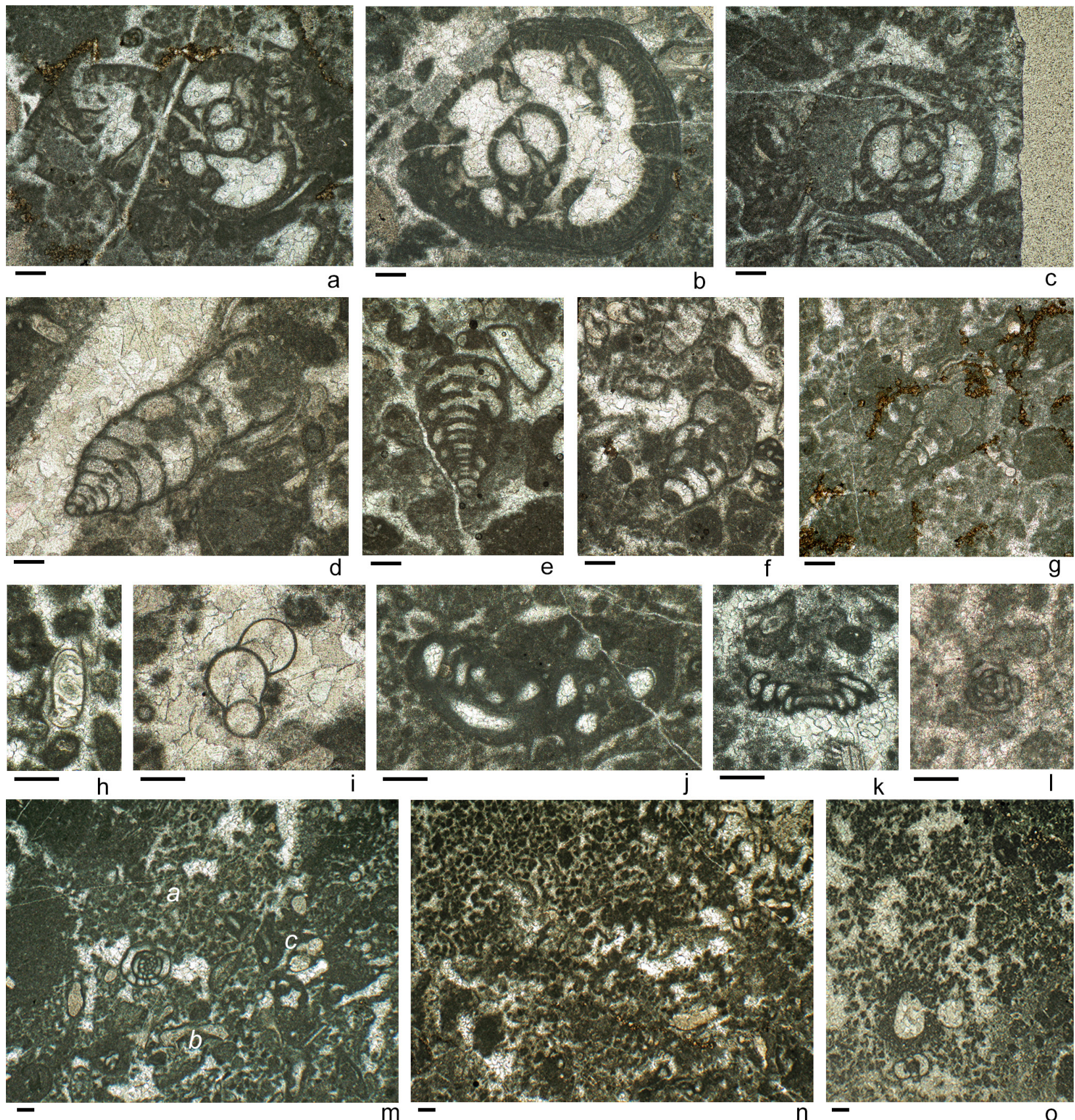

b
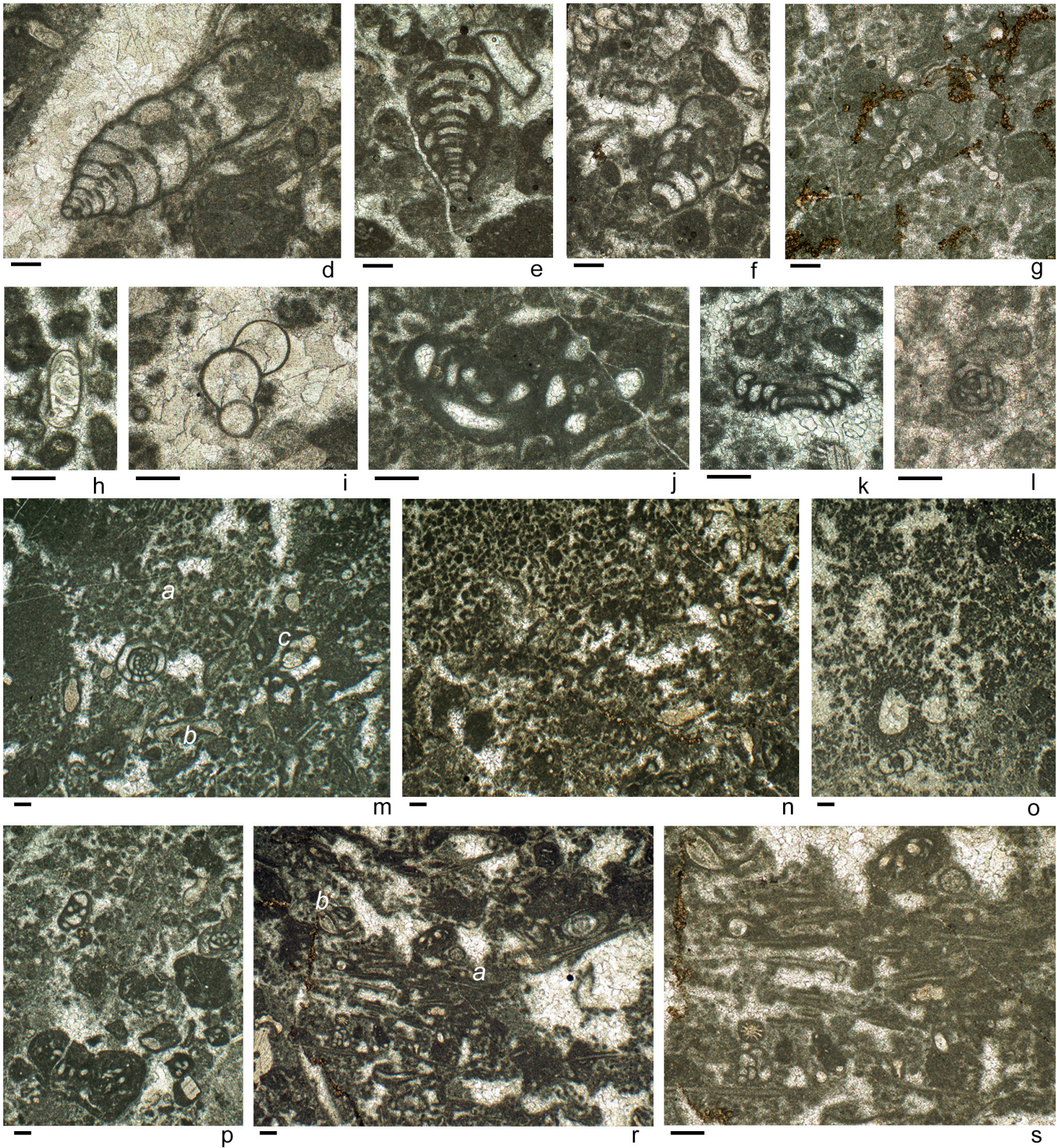

Plate 2. Smaller foraminifera and cyanobacteria from Ljubija, sample BJ 49. Scale bar is 200 microns.

(a-c): Bradyina ex gr. nautiliformis Möller (?B. pseudonautiliformis Reitlinger), (d): Koskinobigenerina aljutovica (Reitlinger), (e): Koskinobigeneriidae, (f): Koskinotextularia posteximium (Reitlinger), (g): Deckerellina cf. mirabilis Reitlinger,

(h): Neoarchaediscus postrugosus (Reitlinger), (i): Tuberitina bulbacea Galloway \& Harlton, (j): ?Tolypammina ex gr. complicata Reitlinger, (k): Postmonotaxinoides cf. horridus (Lipina), (l): Pseudoglomospira cf. elegans (Lipina), (m): a - Filamentforming and cocoid cyanobacteria, $b$ - Donezella sp., $c$ - Anthracoporellopsis sp., (n, o): Filament-forming and cocoid cyanobacteria, (p): Oncolites with Tolypammina fortis Reitlinger, (r): a - Stipulella fascicularis Maslov, b-Donezella sp., (s) Stipulella fascicularis Maslov. 

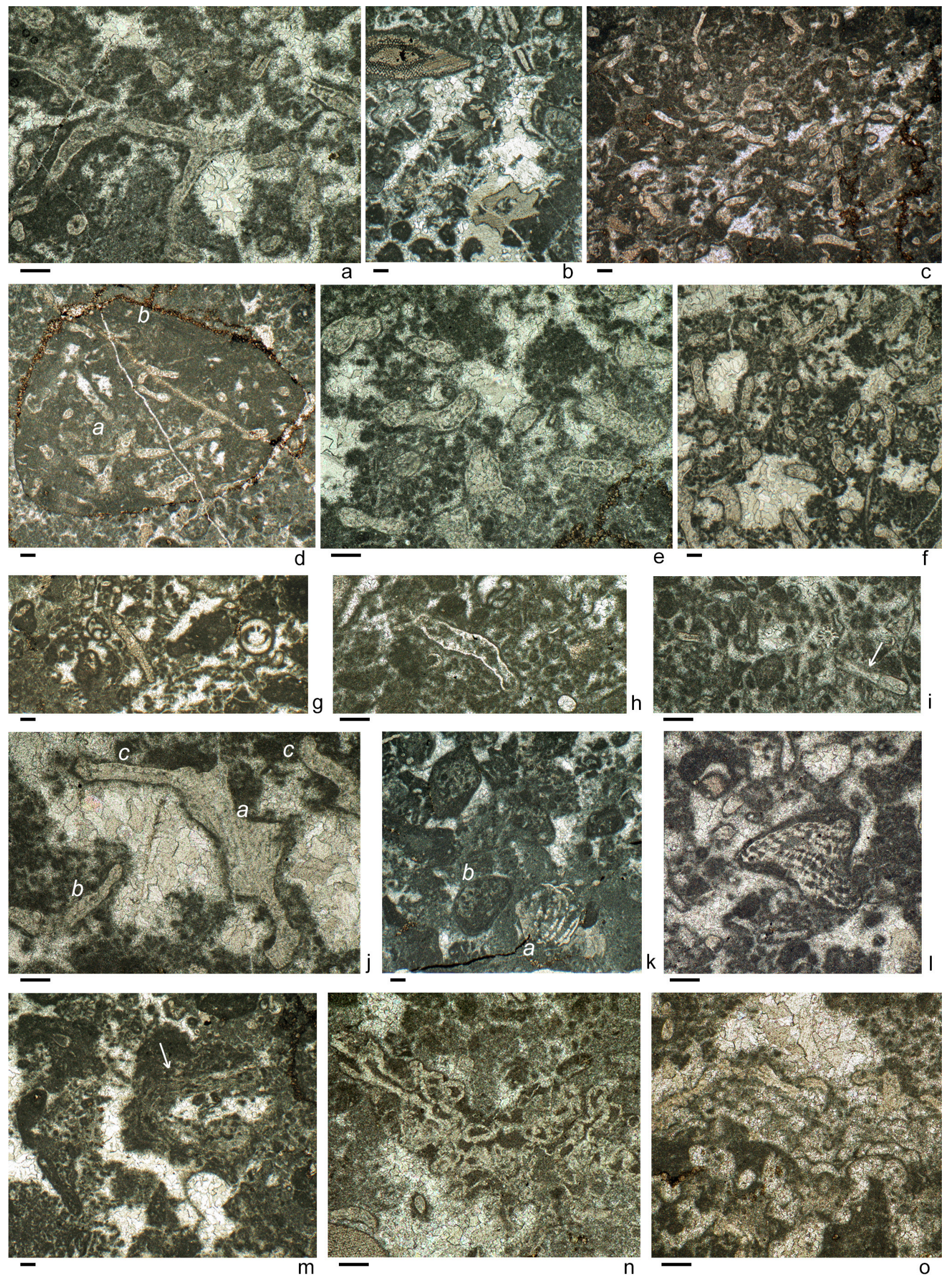

Plate 3. Green and red algae and problematica from Ljubija, sample BJ 49. Scale bar is 200 microns.

(a, b, c): Donezella lutugini Maslov, (d): a - Donezella lutugini Maslov, b-Girvanella sp., (e, f): Donezella lunaensis Racz, (g): Dvinella cf. bifurcata Maslov \& Kulik, (h): Proninella enigmatica Mamet \& Roux, (i): Anthracoporellopsis cf. machaevii Maslov, (j): a-Pseudoungdarella sp. (?P. cf. linearis R. Ivanova), b-Praedonezella cf. cespeformis Kulik, $c$ - ?Donezella sp., (k): $a$ - Stacheia cf. marginulinoides Brady, $b$ - Stacheoides cf. meandriformis Mamet \& Rundloff, (l): Masloviporidium delicata (Berchenko), (m): Stachaeoides sp., (n): Asphaltinella horowitzi Mamet \& Roux, (o): Aphralysia carbonaria Garwood. 
the Serpukhovian Stage of the Urals (Ivanova, 2013), in the Zapaltyubian Regional Substage of the Serpukhovian Stage of the Donets Basin (Berchenko, 1983), and the Visean and Namurian of the Paleo-Tethys (Mamet \& Roux, 1983). Forms similar in morphology, described as Ortonellopsis laxa Vachard \& Cozar were found in the upper Visean - lower Serpukhovian of Montagne Noire, France (Vachard et al., 2016).

Rare algae also occur in thin sections, however of poor preservation. Chlorophyta, represented mainly by Siphonocladales, and also including representatives of the genera Donezella, Dvinella, Proninella, Exvotarisella, Anthracoporellopsis are distinguished by a relative diversity. Donezella is more common with two species: Donezella lutugini Maslov (Pl. 3, Figs. a-d) and D. lunaensis Racz (Pl. 3, Figs. e-f). Both species are characteristic of the Bashkirian and are distributed up to the Asselian Stage of the Lower Permian in Arctic Canada (Mamet et al., 1987), northern Spain (Mamet \& Villa, 2004), northwestern Serbia (Pajić \& Fillipović, 1995) and in Urals, Donets Basin and Tajikistan (Ivanova, 2013). Fragments of Dvinella cf. bifurcata Maslov \& Kulik (Pl. 3, Fig. g), Proninella enigmatica Mamet \& Roux (Pl. 3, Fig. h) and Anthracoporellopsis cf. machaevii Maslov (Pl. 3, Fig. i) thalli were identified. The species Dvinella bifurcata is known from the Middle Carboniferous of the Urals and the East European Platform, from the Bashkirian of northwestern Serbia (Pajić \& Fillipović, 1995), and in northern Greenland it occurs in the Moscovian Stage (Mamet \& Stemmerik, 2000). Proninella enigmatica is described from the upper Visean of North America (Mamet \& Roux, 1978). In the Urals, it was reported from the Tournaisian, upper Visean and Bashkirian (Ivanova, 2013). Anthracoporellopsis machaevii is described from the Middle Carboniferous of the Donets Basin (Maslov, 1956). In Western Europe, it is found in Visean deposits. The stratigraphic range of this species in the Urals is from the upper Visean to the Lower Permian (Ivanova, 2013). In the Moscow Basin it is found in the upper Visean (Gibshman \& Alekseev, 2017).

The studied material also contains two species of Chlorophyta of unclear taxonomic position: Asphaltinella horowitzi Mamet \& Roux and Aphralysia carbonaria Garwood (Pl. 3, Figs. $\mathrm{n}-\mathrm{o})$. The first species is described from the Visean of Canada, southwestern Alberta (Petryk \& Mamet, 1972) and is especially abundant in the Serpukhovian. It occurs in the upper Visean of the Moscow Basin (Gibshman \& Alekseev, 2017), and in the Bashkirian of the Urals (Ivanova, 2013). The species Aphralysia carbonaria is widespread in the Dinantian of England and is known from the upper Serpukhovian of the Donets Basin (Berchenko, 1983).

Rhodophyta include sporadic isolated representatives of the genera Stacheia, Stacheoides, Pseudoungdarella, and Masloviporidium (Pl. 3, Figs. j-1) The species Stacheia marginulinoides Brady is distributed in the upper Visean and Serpukhovian of the Paleo-Tethys (Mamet \& Roux, 1983) and from the Serpukhovian-Bashkirian boundary strata of Alaska (Mamet \& Preat, 2010). On the western slope of the South Urals, it was found in the Bashkirian strata. Stacheoides meandriformis Mamet \& Rundloff is a cosmopolitan species and is known from the Visean of France, Belgium, Morocco, USA, from the Upper Carboniferous of the Canadian Arctic Archipelago, the Permian of Turkey, and the Serpukhovian Stage ranging from the Lower to Upper Carboniferous of the Urals (Ivanova, 2013). The species Masloviporidium delicata (Berchenko) is described from the Serpukhovian Stage of the Donets Basin (Berchenko, 1982). Its geographic distribution is in North Africa (Algeria) and North America where it was assigned to the uppermost Serpukhovian and Bashkirian stages (foraminiferal zones 20 and 21) (Groves \& Mamet, 1985). In the Urals, it is known from the upper Visean to the Bashkirian Stage (Ivanova, 2013). The species Pseudoungdarella linearis Ivanova occurs in the Serpukhovian, Bashkirian and Moscovian of the Urals (Ivanova, 2013).

Thus, the algoflora in the studied block is represented by forms of wide stratigraphic range and geographic distribution. The most important species among them are Donezella lutugini and $D$. cf. lunaensis, which were bioherm-formers and rock-formers in the Bashkirian Stage (Ivanova, 2013; Rodriguez-Castro et al., 2020).

\section{Demospongia}

A specimen of Chaetetes, a hyper-calcified demosponge was collected in the Adamuša opencast mine (Fig. 3). The demosponge fossil (isometric 5-6 cm large skeleton) occurs in a single clast together with coarse matrix and large crinoidal ossicles. Its surface reveals a skeleton consisting of closely connected tubules (diameter $0.3-0.7 \mathrm{~mm}$ ) with indicated radial growth direction. Chaetetids were previously classified as extinct corals, bryozoans, algae, stromatoporoids and sclero- 


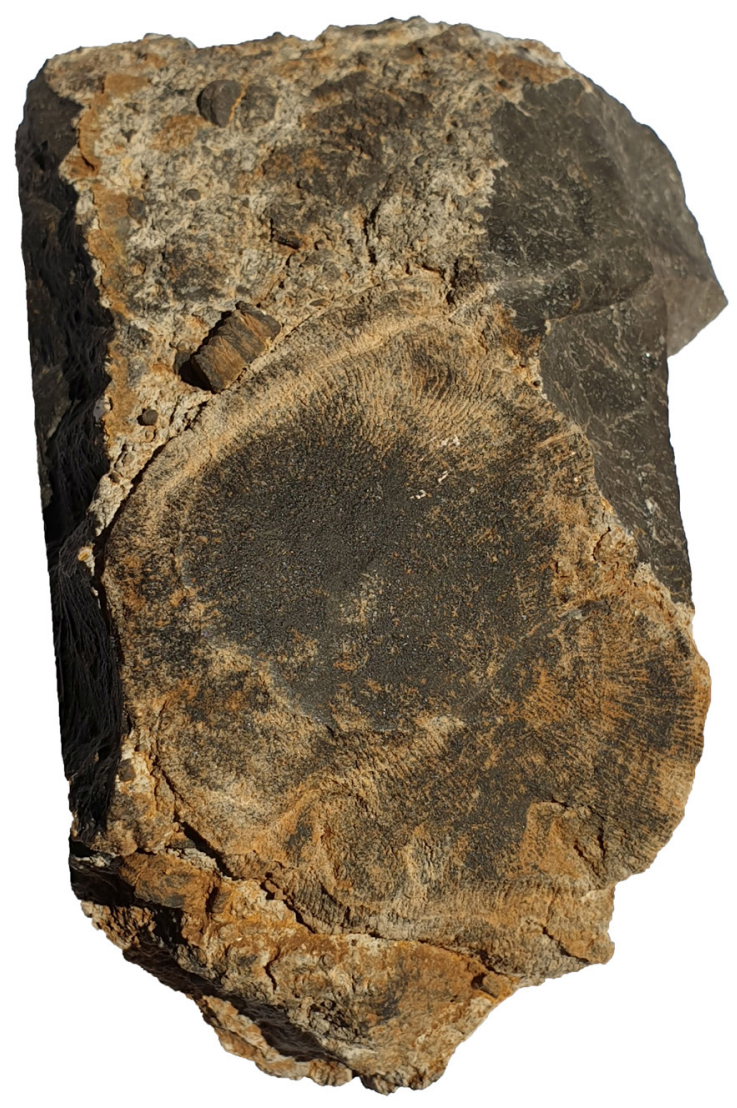

Fig. 3. Chaetetes sp. Adamuša, sample BJ 49. Scale bar $10 \mathrm{~mm}$.

sponges (West, 2011). They grew in very shallow water and formed expansive biostromes (Stanton et al., 2016). The fossil record of chaetetids is known worldwide and they are common in strata ranging from the Ordovician through Jurassic (West, 2011). The species Chaetetes radians that was first described from the Carboniferous of the Moscow Basin (Fischer, 1837) has been already reported from the Ljubija mine area, i.e., in the Jakarina Kosa locality, near Adamuša where it was collected from Carboniferous strata (Kostić-Podgorska, 1959, 1965).

\section{Conodonts}

Despite moderate preservation, five conodont elements can be identified from the sample AT-1 (Fig. 4) at the genus and even species level, which allow dating of the source rock with sufficient accuracy (Fig. 5).

The most important specimen is a right $\mathrm{P} 1$ element without a free blade, but it has slightly curved nodular carina to the rostral margin whose nodes are fused with the nodes of rostral parapet. These characters are indicative for the species Declinognathodus lateralis (Higgins \& Bouckaert) described from the Namurian (Alportian and Kinderscoutian) in Belgium. The species is widely distributed in the lower and middle Bashkirian strata of Great Britain (Higgins, 1975), Donets Basin, Ukraine (Nemyrovska, 1999), South Urals, Russia (Kulagina et al., 2014; Nikolaeva et al., 2017), and South China (Hu et al., 2018). In South China, D. lateralis spans in the middle Bashkirian, with its first occurrence (FO) is in the lower part of the Idiognathoides sinuatus Zone, and its lower occurrence (LO) is in the middle part of the "Streptognathodus" expansus M1 Zone (Hu et al., 2019), but in the South Urals it first appears in the lowermost Bashkirian and its FO coincides with the base of the D. noduliferus Zone (Kulagina et al., 2014).

Three specimens, which are also uncomplete right P1 elements, possess two narrow nodose parapets separated by relatively deep median trough. They belong to the subspecies Idiognathoides sulcatus sulcatus (Higgins \& Bouckaert) that was established on left elements only, but

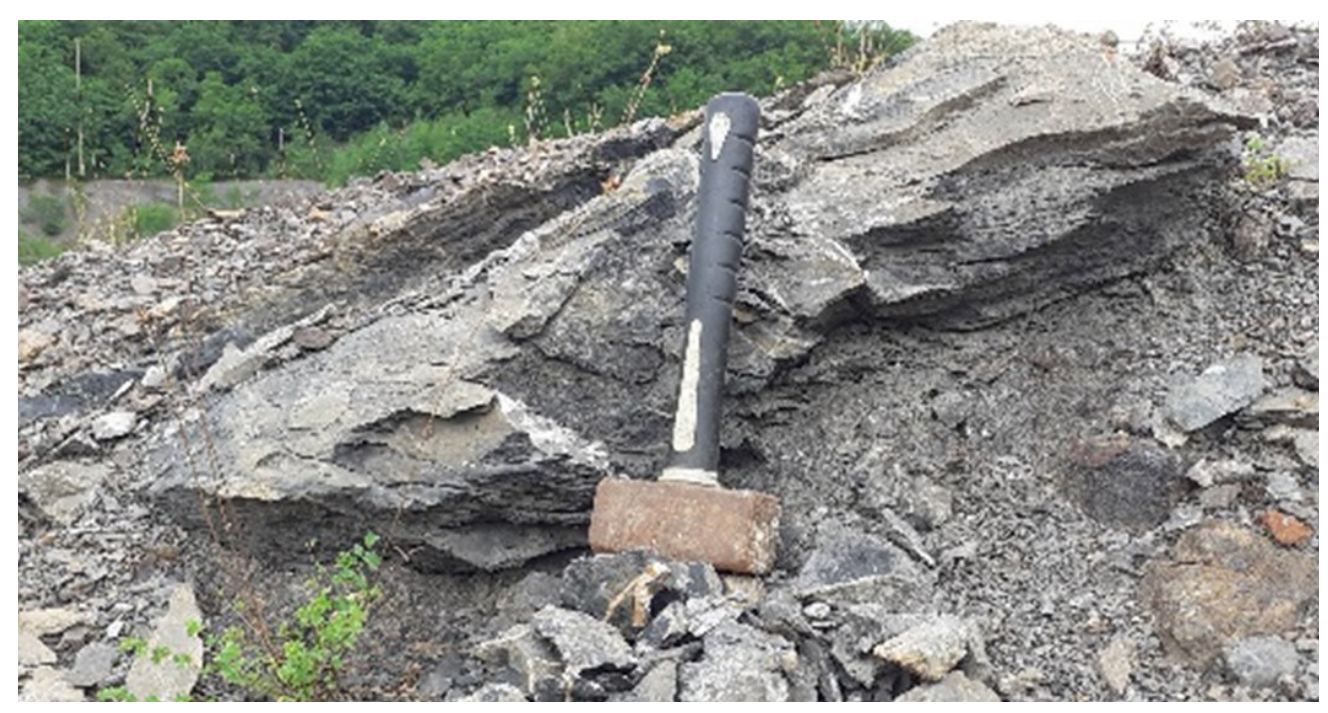

Fig. 4. Outcrop at the Adamuša iron deposit where the limestone sample AT-1 was collected. 
Higgins (1975) illustrated also right elements for this subspecies which are very similar to the ones from Ljubija. This subspecies occurs in the Bashkirian being described from the ammonoid R1-G2 genozones of Belgium (Higgins \& Bouckaert, 1968) and Great Britain (Higgins, 1975), but in South China and the South Urals, Russia, it is found in much younger strata reaching the Bashkirian/Moscovian boundary and even in the lower Moscovian (Kulagina et al., 2001; Hu et al., 2019).

The third conodont morphotype is broken P1 element, without ventral part of the free blade and most of dorsal platform. However, the platform is very wide with no recognized trough. This element belongs to the genus Idiognathodus without any doubts, but the species identification is not possible, therefore the element is assigned to Idiognathodus sp. only.

The FO of the genus Idiognathodus is very important datum plane in the conodont zonations: $I$. primulus marks the Marsdenian (R2 Genozone) of England (Higgins, 1975) and the mid-Bashkirian Idiognathodus primulus Zone of South China (Hu et al., 2019). However, in the type Bashkirian sections of the South Urals the three Idiognathodus species (I. sinuosus Ellison \& Graves; I. delicatus Gunnell and I. primitivus (Nemirovskaya \& Alekseev)) occur in the middle Bashkirian interval, at the base of the Askynbashian Substage (Kulagina et al., 2001).

The joint presence of the species Declinognathodus lateralis, Idiognathoides sulcatus sulcatus and Idiognathodus sp. confirms a mid-Bashkirian age of the source rocks, which is the Askynbashian and lower Arkhangelskian substages in the Russian stratigraphic nomenclature (Alekseev, 2008).

A strange character of the Ljubija conodont assemblage is the absence of Idiognathoides corrugatus (Harris \& Hollingsworth) and Id. sinuatus Harris \& Hollingsworth, two ubiquitous Bashkirian and early Moscovian species, that might be explained by very lower count of the extracted conodont elements (only five). The assemblage belongs to the outer shelf and slope Declinognathodus-Idiognathoides biofacies (Davis \& Webster, 1985).

In the Spanish Pyreneans, the assemblage of the Idiognathodus Zone is similar to the one from Ljubija that is present in the Quinto-Real area in the upper part of the Baserdi Member of the Olazar Formation, in the siliciclastic Kulm-type unit interpreted as Kinderscoutian-Marsdenian in age (Sanz-López \& Blanco-Ferrera, 2012).
A joint occurrence of several species of Idiognathodus and Declinognathodus lateralis is known also in the Namurian C (G1 Zone) limestone bands $\mathrm{M}, \mathrm{N}$ and $\mathrm{P}$ in the Lublin Basin, Poland (Skompski, 1996). In the Donets Basin the FO of Idiognathodus sinuosus is in the Limestone F11, upper part of the Mandrykian Regional Substage, middle Bashkirian, where it occurs together with D. lateralis (Nemyrovska, 1999, 2017). If the Ljubija area has a relation to the North Gondwana Realm, very similar conodont assemblage including D. lateralis and Idiognathodus is reported from the Bechar Basin, Algeria, from marine inner shelf of the Hassi Kerama Formation of the middle Bashkirian age (Weyant, 1985).

Bashkirian conodonts are not common in Great Britain and Western Europe, where they are known only from England (Higgins, 1975), Belgium (Higgins \& Bouckaert, 1968), Germany (Meischner, 1970) and Poland (Skompski, 1996). In these countries, conodonts of this age occur only in marine horizons inside of coal-bearing terrestrial sequences, but they are widely distributed in marine carbonate successions of the French and Spanish Pyreneans as well in the Cantabrian Mountains of North Spain.

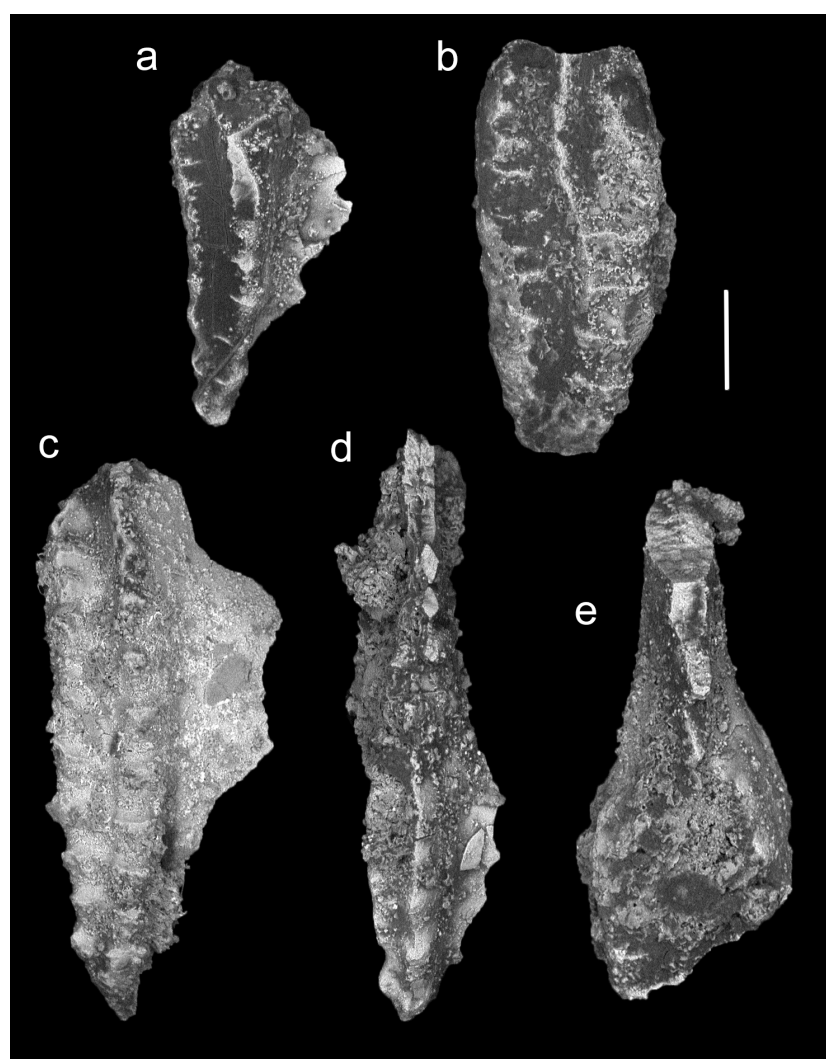

Fig. 5. Conodonts from Ljubija, sample AT-1 (GeoZS 6220). Scale bar is 100 microns.

(a, c, d) Idiognathoides sulcatus sulcatus Higgins \& Bouckaert, (b) Declinognathodus lateralis (Higgins \& Bouckaert), (e) Idiognathodus sp. 


\section{Conclusions}

Biota obtained from limestone samples of the Olistostrome member of the Adamuša site in the Ljubija area in western Bosnia and Herzegovina have been examined. The limestone sample AT-1 is marked by the joint presence of Declinognathodus lateralis, Idiognathoides sulcatus sulcatus and Idiognathodus sp. confirming the mid-Bashkirian age of the primary rocks. This report is the first of the listed conodont taxa in the area. The Ljubija conodont assemblage is similar to the Declinognathodus-Idiognathoides biofacies of the outer shelf and slope. On the other hand, it can also be compared to an equivalent conodont assemblage of marine inner shelf in Algeria.

The chaetetid demospongia (from sample BJ) is associated with a prolific microbiota consisting of cyanobacteria, algae and foraminifera. Microfacies of the rock is peloidal bioclastic grainstone to packstone. Cyanobacteria are common and exhibit great similarity to the known Bashkirian filament-forming and coccoid bacteria remains. Chlorophyta are dominated by Siphonocladales of relative diversity, among which are common Donezella lutugini and D. cf. lunaensis that are characteristic of the Bashkirian. Rhodophyta include sporadic isolated representatives of the genera Stacheia, Stacheoides, Pseudoungdarella and Masloviporidium. The biota also contains two species of unclear taxonomic position, Asphaltinella horowitzi and Aphralysia carbonaria. Foraminiferal assemblage consists of pseudostaffellids, eostaffellids and smaller foraminifera, mostly endothyrids. The presence of the foraminiferal species Pseudostaffella antiqua points to the Bashkirian age. The association of the endothyrids, staffellids and bradyinids indicates their primary habitat was linked to a high-energy reef environment that is confirmed by the presence of Donezella siphonoclads, which formed bioherms during the Bashkirian.

\section{Acknowledgments}

This work was partially supported by the Slovenian Research Agency (program number P10011). Facilities and technical staff of the Geological Survey of Slovenia are gratefully acknowledged. The authors are indebted to Galina P. Nestell and Merlynd $K$. Nestell for editing the manuscript and two anonymous reviewers who provided constructive reviews of the manuscript.

\section{References}

Alekseev, A.S. 2008: Carboniferous System. In: Zhamoida, A.I. \& Petrov, O.V. (eds.): The state of knowledge of the stratigraphy of the Precambrian and Phanerozoic in Russia. Tasks for further research. Postan. Mezhved. Strat. Komit. Postoy. Komis., 38: 61-68. (In Russian)

Aretz, M., Herbig, H.G. \& Wang, X.D. 2020: Carboniferous Period. In: Gradstein, F.M., Ogg, J.G., Scmitz, M.D. \& Ogg, G.M. (eds.): Geological Time Scale 2020. Elsevier, 2: 811-874.

BouDagher-Fadel, M. 2008: Chapter 2 The Palaeozoic larger benthic foraminifera: The Carboniferous and Permian. In: Evolution and Geological Significance of Larger Benthic Foraminifera. Developments in Palaeontology and Stratigraphy, 21: 45-125. https://doi. org/10.1016/S0920-5446(08)00002-2

Berchenko, O.I. 1982: New species of green algae from upper Serpukovian deposits of Donets Basin. In: Systematics and evolution of ancient flora of Ukraine. Kiev: Naukova Dumka: 51-55. (In Russian)

Berchenko, O.I. 1983: Calacareous algae in Upper Serpukhovian of Donets Basin (paleontological characteristic). In: Didkovsky, V.Ya. (ed.): Systematics and evolution of ancient flora of Ukraine, Kiev. Naukova Dumka: 123-131. (In Russian)

Crnolatac, I. 1949: Tumač geološkoj karti sjevernih i južnih revira ljubijskih rudišta. Tumač u Fondu stučnih dokumenata RŽR Ljubija. Prijedor: $10 \mathrm{p}$.

Davis, L.E. \& Webster, G.D. 1985: Late Mississippian to Early Pennsylvanian conodont biofacies in central Montana. Lethaia, 18/1: 67-72. https:// doi.org/10.1111/j.1502-3931.1985.tb00685.x

Della Porta, G., Villa, E. \& Kenter, J.A.M. 2005: Facies distribution of Fusulinida in a Bashkirian-Moscovian (Pennsylvanian) carbonate platform top (Cantabrian Mountains, NW Spain). Journal of Foraminiferal Research, 35/4: 344-367. https://doi. org $/ 10.2113 / 35.4 .344$

Dingle, P.S., Bader, B., Hensen, C., Minten, B. \& Schäfer, P. 1993: Sedimentology and paleoecology of Upper Carboniferous shallow-water carbonate complexes of the Cármenes Syncline (Cantabrian Mts., N-Spain). Z. Deut. Geol. Gesell., 144: 370-395. https://doi. org/10.1127/zdgg/144/1993/370

Dzhenchuraeva, A.V., Neevin, A.V., Maksumova, R.A., Getman, O.F. \& Nogaeva, L.P. 2013: The 
Atlas of facies and fossils of the Paleozoic of Middle Tien-Shan. In: Dzhenchuraeva, R.D. (ed.): Bishkek: 404 p. (In Russian)

Fischer de, W.G. 1837: Oryctographie du Gouvernement de Moscou. Semen, Moscou: $202 \mathrm{p}$.

Gallagher, S.J. 1998: Controls on distribution of calcareous Foraminifera in the Lower Carboniferous of Ireland. Mar. Micropaleont., $34: 187-211$. https://doi.org/10.1016/ S0377-8398(98)00006-1

Gallagher, S.J. \& Somerville, I.D. 2003: Lower Carboniferous (late Viséan) platform development and cyclicity in southern Ireland: foraminiferal biofacies and lithofacies evidence. Riv. Ital. Paleont. Strat., 109/2: 159-171. https://doi.org/10.13130/2039-4942/5499

Garašić, V. \& Jurković, I. 2012: Geochemical charasteristic of different iron ore types from the Southern Tomašica deposit, Ljubija, NW Bosnia. Geol. Croat., 65/2: 255-270. https:// doi.org/10.4154/GC.2012.16

Gibshman, N.B. \& Alekseev, A.S. 2017: Marine algal flora of the Late Visean (Early Carboniferous) of the Moscow Basin. Paleontological J., 53/3: 313-325. https://doi. org/10.1134/S0031030117020071

Groves, J.R. \& Mamet, B.L. 1985: Masloviporidium, a cosmopolitan Middle Carboniferous Red Alga. In: Toomey, D.F. \& Nitecki, N.H. (eds.): Paleoalgology: contemporary research and applications. Springer Verlag, Heiledberg: 85-90.

Grozdilova, L.P. \& Lebedeva, N.S. 1950: Some species of Staffella of Middle Carboniferous deposits of the western slope of the Urals. Trudy Vsesoyuznogo neftyanogo geologo-razvedochnogo instituta, 50: 5-45. (In Russian)

Grubić, A., Protić, L., Filipović, I. \& Jovanović, D. 2000: New data on the Paleozoic of the SanaUna area. Zbornik radova geologija i metalogenija Dinarida i Vardarske zone. Akademija nauka i umj. RS, Banja Luka: 49-54.

Grubić, A. \& Protić, L. 2003: Studija strukturnih i genetskih karakteristika Tomašičkog rudnog polja. In: Cvijić, R. (ed.): Novi prilozi za geologiju i metalogeniju rudnika gvožđa Ljubija. Rudarski institut, Prijedor: 63-137.

Grubić, A., Cvijić, R., Milošević, A. \& Čelebić, M. 2015: Importance of olistostrome member for metallogeny of Ljubija iron ore deposits. Arch. Techn. Sci., 13/1: 1-8. https://doi. org/10.7251/afts.2015.0713.001G

Heritsch, F. 1940: Korallen aus dem Oberkarbon im Gebiete der Sana in Bosnien. Sitzungsb.
Akad. Wiss. Math.-Nat. Kl. Abt. I, Bd. 2: 147-155.

Higgins, A.C. 1975: Conodont zonation of the late Viséan - early Westphalian strata of the south and central Pennines of northern England. Bull. Geol. Surv. Great Brit., 53: 90 p.

Higgins, A.C. \& Bouckaert, J. 1968: Conodont stratigraphy and palaeontology of the Namurian of Belgium. Mém. Serv. Éxplic. Cartes géol. Min. Belg., Mémoire, 10: 51 p.

Hrvatović, H. 2006: Geological guidebook through Bosnia and Herzegovina. Separate Monograph of Herald Geological. Geological Survey of Federation of Bosnia and Herzegovina, Sarajevo: 164 p.

Hu, K., Qi, Y. \& Nemyrovska, T. 2018: MidCarboniferous conodonts and their evolution: new evidence from Guizhou, South China. J. Syst. Palaeont. https://doi.org/10.1080/147720 19.2018.1440255

Hu, K., Qi, Y., Qie, W. \& Wang, Q. 2019: Carboniferous conodont zonation of China. Newslett. Strat. https://doi.org/10.1127/ nos/2019/0498

Ivanova, R.M. 2013: Calcareous algae of the Carboniferous of the Urals. Yekaterinburg: RIO UrO RAN, 2013: 244 p. (In Russian).

Jurić, M. 1971: Geologija područja sanskog paleozoika u sjeverozapadnoj Bosni. Poseb. Izd. Geol. glas., 11: 1-146.

Jurić, M. 1975: Tumač Osnovne geološke karte SFRJ, 1:100 000 list Prijedor. Savezni geološki zavod, Beograd: 55 p.

Katzer, F. 1910: Die Eisenerzvorrete Bosniens und der Hercegovina. Sonderb. Berg und Huettenmann Jb., Wien: 58.

Katzer, F. 1921: Geologische Übersichtskarte von Bosnien-Herzegovina, 1:200.000 Drittes Sechstellblat: Banja Luka. Wien.

Katzer, F. 1926: Geologija Bosne i Hercegovine. Sarajevo. Direkcija državnih rudarskih preduzeća. Sarajevo: 520 p.

Kostić-Podgorska, V. 1955: Donjokarbonski korali iz paleozoika reke Sane (Bosna). Zbornik radova geološkog instituta Jovan Žujović, 8, Beograd: 169-177.

Kostić- Podgorska, V. 1959: Izvještaj o istraživanju makrofaune iz područja Rudnika Ljubija. Prilog (6 p.) u Izvještaju o geološkom istraživanju Sanskog paleozoika (centralni dio). Zavod za geološka istraživanja i ispitivanja građevinskog materijala i tla, Sarajevo: 61 p.

Kostić - Podgorska, V. 1965: Izvještaj o proučavanju paleontološkog materijala sa područja Sanskog paleozoika. Prilog II (8 p.) u 
Godišnjem Izvještaju o regionalnom geološkom istraživanju paleozoika Sane za 1964. godinu. Geološki zavod, Sarajevo: $88 \mathrm{p}$.

Kulagina, E.I. 2014: Volumes and boundaries of subdivisions of the International Carboniferous Stratigraphic Scale in the South Urals. Geologicheskiy sbornik 7, Yubileynyy vypusk: 205-218. (In Russian).

Kulagina, E.I. \& Gorozhanina, E.N. 2019: Foraminifers from the Bashkirian Stage (Middle Carboniferous) Deposits of the Southern Part of the Cis-Uralian Foredeep. Paleont. J., 53: 956-960. https://doi. org/10.1134/S0031030119090065

Kulagina, E., Nikolaeva, S., Pazukhin, V. \& Kochetova, N. 2014: Biostratigraphy and lithostratigraphy of the Mid-Carboniferous boundary beds in the Muradymovo section (South Urals, Russia). Geol. Mag., 151/2: 269-298. https://doi.org/10.1017/S0016756813000599

Kulagina, E.I., Pazukhin, V.N., Kochetkova, N.M., Sinitsyna Z.A. \& Kochetova, N.N. 2001: Stratotype and reference sections of the Bashkirian Stage in South Urals. Gilem, Ufa: 138 p. (In Russian)

Lipina, O.A. 1973: Zonal stratigraphy and paleobiography of Tournaisian on foraminifers. Voprosy micropaleontologii. Nauka, Moscow, 16: 4-35. (In Russian)

Mamet, B. \& Preat, A. 2010: Un Atlas d algues calcaires. Carbonifere. Alasca Arctique. http://paleopolis.rediris.es/cg/BOOKS/ CG2010_SP01/

Mamet, B. \& Roux, A. 1978: Algues Viseenes et Nammuriennes du Tennessee (Etats-Unis). Rev. Micropal., 21/2: 68-97.

Mamet, B. \& Roux, A. 1983: Algues DevonoCarboniferes de L'Australie. Rev. Micropal., 26/2: 6-131.

Mamet, B.L. \& Stemmerik, L. 2000: Carboniferous algal microflora, Kap Jungersen and Foldedal formatios, Holm Land and Amdrup Land, eastern North Greenland. Geology of Greenland Survey Bulletin 187: 79-101. https://doi.org/10.34194/ggub.v187.5196

Mamet, B. \& Villa, E. 2004: Calcareous marine algae from the Carboniferous (MoscovianGzhelian) of the Cantabrian Zone (NW Spain). Revista Espanola de Paleontologia, 19/2: 151-190.

Mamet, B.L., Roux, A. \& Nassichuk, W.W. 1987: Algues carboniferes et permiennes de l'Artique canadien. Geological Survey of Canada, Bulletin, 342: 143 p. https://doi. org/10.4095/122452
Maslov, V.P. 1956: About a new fossil family of Rhodophyta and two new genera of blue-green algae of the Carboniferous. Doklady Akademii Nauk SSSR, 107/1: 151-154. (In Russian)

Meischner, D. 1970: Conodonten-Chronologie des Deutschen Karbons. In: Sixième Congrès International de Stratigraphie et de Géologie du Carbonifère. Sheffield, 11th to 16th September 1967. Compte Rendu. Publishing Company and Printing Works Ernest van Aelst, Maastricht, 3: 1169-1180.

Milošević, A., Grubić, A., Cvijić, R. \& Čelebić, M. 2017: Annexes the knowledge of the metallogenia of the Ljubia mineral area. Book of Proceedings, 7th Balkanmine congress, Prijedor: 57-68.

Mojsisovics, E., Tietze, E. \& Bittner, A. 1880: Grundlinien der Geologie Bosnien und Herzegowina. Jb. Geol. R.-A., Wien, 30: 1-100.

Nemyrovska, T.I. 1999: Bashkirian conodonts of the Donets Basin, Ukraine. Scr. Geol., 119: 1-115.

Nemyrovska, T.I. 2017: Late MississippianMiddle Pennsylvanian conodont zonation of Ukraine. Stratigraphy, 14/1-4: 299-318.

Nikolaeva, S.V., Kulagina, E.I., Gorozhanina, E.N., Alekseev, A.S. \& Konovalova, V.A. 2017: Conodonts, ammonoids, foraminifers, and depositional setting of the Serpukhovian and Bashkirian stages in the Kugarchi Section in the South Urals, Russia. Stratigraphy, 14/1-4: 143-178.

Noeth, L. 1952: Die Eisenerzlagerstaetten Jugoslawiens. XIX Intern. Geol. Congr., Symposium sur. les gisements de fer du mond, 2, Alger: 529-563.

Pajić, V. \& Fillipović, I. 1995: Foraminifers and algae. In: Fillipović, I. (ed.): The Carboniferous of northwestern Serbia. Rasprave Geološkog zavoda "GEMINI", T. 25: 50-59.

Palinkaš, A.L. 1990: Siderite-barite-polysulfide deposits and early continental rifting in Dinarides. Geol. Vj., 43: 181-185.

Palinkaš, A.L., Borojević-Šoštarić, S., StrmićPalinkaš, S., Prochaska, W., Pecskay, Z., Neubauer, F. \& Spangenberg, J.E. 2016: The Ljubija geothermal field: A herald of the pangea break - up (NW Bosnia and Herzegovina). Geol. Croat., 69/1: 137-165. https://doi. org/10.4154/GC.2016.02

Petryk, A.A. \& Mamet, B.L. 1972: Lower Carboniferous Algal Microflora, Southwestern Alberta. Canadian Journal of Earth Sciences, 9/7: 767-802. 
Ramovš, A. 1990: Ein Conodontenfauna aus dem Unterkarbon suedlich des Eisenbergwerkes Ljubija, West-Bosnien. Geol. Palaeont., 24: 109-113.

Rauser-Chernousova, D.M., Gryzlova, N.D., Kireeva, G.D., Leontovich, G.E., Safonova, T.P. \& Chernova, E.I. 1951: Middle Carboniferous fusulinids of the Russian Platform and adjacent regions. Akademia Nauk SSSR, Inst. Geol. Nauk, Min. Neft. Promysh. SSSR, Trudy: 380 p. (In Russian)

Rodriguez-Castro, I., Rodriguez, S. \& FregenalMartinez, M. 2020: Donezella-chaetetid mounds in the Valdeteja Formation (Bashkirian, Pennsylvanian) at Truebano, Cantabrian Mountains, northern Spain. Boll. Soc. Paleont. Ital., 59/3: 247-259.

Sanz-López, J. \& Blanco-Ferrera, S. 2012: Lower Bashkirian conodonts from the Iraty Formation in the Alduides-Quinto Real Massif (Pyrenees, Spain). Geobios, 45/4: 397-411. https://doi.org/10.1016/j.geobios.2011.09.003

Simić, V. 1940: Gornjokarbonski fosili Kraninog potoka kod Ljubije u SZ Bosni. Ves. Geol. Inst. Kralj. Jugosl., 8: 85-95.

Skompski, S. 1996: Stratigraphic position and facies significance of the limestone bands in the subsurface Carboniferous succession of the Lublin Upland. A. Geol. Polon.: 46/3-4: 171-268.

Spasov, H. \& Filipović, I. 1966: Konodontska fauna starijeg i mlađeg paleozoika JI i SZ Bosne. Geol. Glas., 11: 33-53.

Stanton, R.J.Jr., Lambert, L.L., Webb, G.E. \& Lustig, L.D., 2016: Chaetetes morphology, environment and taxonomy. Facies, 62/29. https://doi.org/10.1007/s10347-016-0479-3
Stefanovska, D. 1990: Zaključci o rezultatima sedimentoloških ispitivanja karbonskog kompleksa. Rud.-geol. fak., Beograd: 1-8.

Stojanović-Kuzenko, S. 1967: Biostratigrafija srednjeg karbona zapadne Srbije i paralelizacija sa severozapadnom Bosnom, jednim delom Velebita i Stanišićima u Crnoj Gori. Ves. zav. geol. geof. istraž., 24-25 (1966/67), Beograd: 221-241.

Strmić-Palinkaš, S., Spangenberg, J.E. \& Palinkaš, A.L. 2009: Organic and inorganic geochemistry of Ljubija siderite deposits, NW Bosnia and Herzegovina. Min. Deposita, 44/8: 893-913. https://doi.org/10.1007/ S00126-009-0249-Z

Vachard, D., Cozar, P., Aretz, M. \& Izart, A. 2016: Late Visean-Early Serpukhovian cyanobacteria and algae from the Montagne Noire (France); taxonomy and biostratigraphy. Bull. Geosci., 91/3: 433-466.

West, R.R.2011: PartE, Revised, Volume 4, Chapter 2A: Introduction to the fossil hypercalcified chaetetid-type Porifera (Demospongiae). Treatise Online, 20: 1-79.

Weyant, M. 1985: North Africa. Conodonts. In: Martinez Diaz, C., Wagner, R.H., Winkler Prins, C.F. \& Granados, L.F. (eds.): The Carboniferous of the World. II. Australia, Indian Subcontinent, South Africa, South America \& North Africa. IUGS Publ. 20. Empresa nacional adaro de invest. mineras, s.a., Madrid: 364-367.

Zaytseva, E.L. \& Klenina, L.N. 2008: The boundary of the Lower and Middle Carboniferous of Pricaspian depression. Byulleten' Moskovskogo obshchestva ispytateley prirody. Geol. Series 88/2: 22-49. (In Russian). 